\title{
THE NEW COMPANION TO URBAN DESIGN
}

Edited by Tridib Banerjee and Anastasia Loukaitou-Sideris 


\section{CONTENTS}

List of contributors $\quad x i$

Introduction: challenges and aspirations of urban design 1

Part I: Comparative urbanism $\quad 9$

\section{PART I.I}

$\begin{array}{ll}\text { Arguments and observations } & 11\end{array}$

1 Comparative urbanism: design in translation 15 Fran Tonkiss

2 Fishbowl city: postcolonial Los Angeles and the philosophy of the urban 28 Ananya Roy

\section{PART I.II}

Regional experiences

3 Globalization, resiliency, and change: Latin American urban design in the 21 st century

Lawrence A. Herzog

4 Spatial justice and urban design: the case of Southern African settlements 
5 The fading pulse of place: Eastern Mediterranean cities in the neoliberal era

Ramzi Farhat

6 Un-cities: the urbanism of rapidly growing cities in the Gulf region Surajit Chakravarty

\section{Part II:}

Challenges

\section{PART II.I}

Claims and conflicts

7 Immigrants, mosques, and religious pluralism: challenges for urban design and planning

Stefano Moroni, Francesco Chiodelli, Elena Porqueddu, and Anna Botta

8 Claiming ordinary space in the "cosmopolitan grid": the case of Singapore

Felicity H.H. Chan

9 Designing for difference in Barcelona's el Raval Jeremy Németh

\section{PART II.II}

Informality

10 Informal settlement as a mode of production Kim Dovey

11 The new geographies and spatialities of informality Annette M. Kim

12 Urban informality and the city at night

Su-Jan Yeo

13 Urban design and informal urbanism: case studies from

Delhi and Mumbai

Manish Chalana

14 The everyday exceptionalism of temporary settlements: the role of urban design response

Rachel Berney 


\section{PART II.III}

15 The insurmountable opportunities of explosive growth: urban design in China

Daniel B. Abrarnson

16 Urban space design for hybrid and high-density environments Im Sik Cho

17 Shrinking cities, shrinking world: urban design for an emerging era of global population decline

Brent D. Ryan

18 From abandonment to urban qualities? Urban design strategies for shrinking cities in Germany and the United States

Karina Pallagst, René Fleschurz, and Sabrina Förch

19 Designing the shrinking city

Justin B. Hollander

\section{PART II.IV}

20 The design of large-scale redevelopment projects Alexander Garvin

21 From town hall to town plan: the case of Byblos, Lebanon

Sandra Frem and Hashim Sarkis

\section{PART II.V}

\section{Gentrification and displacement}

22 Inner-ring suburban retrofit and neighborhood change in the post-suburban era

Suzanne Lanyi Charles and Richard B. Peiser

23 Unsmart outcomes of the smart city initiatives: displacement and peripheralization in Indian cities 
PART II.VI

Mimesis and simulacra

24 Between simulation and authenticity: the question of urban remaking

Scott A. Lukas

25 Glocalizing themed spaces: the creation of urban spaces in China, Asia, and other regions

Li Xiangning

26 Travels in duplitecture

Bianca Bosker

27 Improvised urbanism in the design of India's unauthorized colonies

D. Asher Ghertner

Part III: Aspirations

\section{PART III.I}

Resilience and sustainability

28 Pursuing resilient urban design: equitably merging green and gray strategies

Zachary Lamb and Lawrence J. Vale

29 Reducing vulnerabilities through urban design: interventions for resilience in communities at risk

Diane E. Davis

30 Planning the risk city: emerging practices

Yosef Jabareen

31 The potential of SITES for urban design

Frederick Steiner and Rebecca S. Popowsky

\section{PART III.II}

Health

32 Refocusing planning and design to maximize public health benefits

Richard J. Jackson and Rebecca Ferdman

33 A new health urbanism

Jenny Roe 
34 Complete and healthy streets

Lawrence Frank, Jared Ulmer, Bruce Appleyard, and Alexander Bigazzi

\section{PART III.III}

\section{Conservation/restoration}

35 Broadening heritage conservation through urban design: perspectives from Asia

Vinayak Bharne

36 Heart of Shenzhen: the movement to preserve "Ancient"

Hubei village

Mary Ann O'Donnell

37 Planning modernity in Kabul: urban design as developmental politics Pietro Calogero

\section{PART III.IV}

Justice

38 Justice and urban design

Bryce C. Lowery and Lisa A. Schweitzer

39 Toward transformative urban spatial change: views from Jakarta Kian Goh

\section{PART III.V}

Intelligence

40 Tarzan vs. IBM: value paradigms of urban technologies Dietmar Offenhuber

41 Smart citizens, participatory urbanism, and the future of city design

Jennifer Stein and Scott Fisher

42 Designing cities within emerging geographies: the work of Senseable City Lab

Fábio Duarte and Carlo Ratti

43 Intelligence for place-making and social inclusion: critiques and alternatives to India's Smart Cities Mission 


\section{PART III.VI}

Mobility and access

44 Accessibility-oriented urban design

Susan Handy

45 Mobility, accessibility, and urban form

Yodan Y. Rofe

46 Modernism, pedestrians, and public space: a century of North American street design

Paul Hess, Kelly Gregg, and Ryan Whitney

47 Aerial mobility, transport infrastructure, and urban design in Asian cities

Max Hirsh

\section{PART III.VII}

Arts and culture

48 Designing the inclusive city: urban cultures, street arts, and public life Renia Ehrenfeucht

49 Painting insurgent artscapes

Stefano Bloch

50 Urban design and public art on Instagram

Brettany Shannon

Epilogue

Index 